\title{
The quality of teaching and professional development of teachers: a Portuguese study
}

\author{
Rosalinda Herdeiro* and Ana Maria Costa e Silva \\ Institute of Education, University of Minho, Braga, Portugal
}

(Received 2 August 2011; final version received 7 June 2012)

\begin{abstract}
This paper is part of a research study undertaken with Portuguese teachers. The main objective is to understand the impact of recent educational legislation on the quality of teaching and the professional development of teachers. In this context the following research questions were formulated: 'Do the education policies of the government encourage teacher development?', 'Will opportunities for teacher development be created in schools?', 'Will the goal of improving the quality of teaching be achieved in education contexts sustained by teaching malaise?' This paper seeks to explain the perceptions of elementary school teachers recounted in written and oral biographical narratives and in three discussion groups set up for the purpose. The professional experiences recounted by the teachers suggest outcomes different from those foreseen by educational policymakers, thus emphasising the weaknesses and inapplicability of the core objectives established by recent Portuguese legislation.
\end{abstract}

Keywords: education policy; biographical narratives; teaching quality; teaching malaise; professional development

\section{Introduction}

The first part of this article will refer to the political and theoretical contextualisation of education, professional development and the quality of teaching. Recent Portuguese educational policies will be mentioned in order to allow the authors to identify the increasing concern about the quality of teaching and teacher training, as well as (national and international) studies and questions concerning professional development.

In the second part the research methodology of the study, sample characteristics and some of the main results that have been gathered concerning the quality of teaching and professional development of teachers will be presented.

At a time of complexity and change, European schools and particularly their teachers have often been faced with (new) demanding challenges that entail ever more refined professional skills, which have repercussions on teachers' work, professional development and careers.

In the last few decades, the transformations that have occurred have shaken up the autonomy of teachers, situating them in the presence of challenges and demands of a process of continuous development throughout their careers (Day 2001). Indeed

*Corresponding author. Email: rosalinda.herdeiro@gmail.com 
they question the significance of being a professional in a work context marked out by accountability and excessive control of their work (Ball 2002; Hill 2010).

The studies of Day and Gu (2010) demonstrate, amongst other aspects, that the educational contexts dominated by processes of accountability and control multiply the tasks of teachers, thus diverting them from their teaching function, which leads to the emergence of new demands and teaching experiences that can jeopardise the quality desired in teaching.

According to Caetano (2007, 107), the change is not compatible 'with closed systems pre-determined by economic goals that, in many countries, increasingly are being imposed', implying, in this way, more than ever, the assumption of an 'independent and critical voice' that questions the reforms and routes rooted in accountability and ideological obedience (Hargreaves 1998; Goodson 2008).

So policies for change should benefit from the promotion of healthy education environments, i.e. ones that see the school not simply as a source of information but, more importantly, as a place of motivation and learning - for both students and teachers.

Education needs qualified teaching acquired in different ways from those used so far (UNESCO 2005; Canário 2007; Darling-Hammond 2010), which are basically focused on the professional development of teachers with an 'emphasis on collaboration, co-operation between teachers and anyone else who is legally responsible for education' (Day and Sachs 2004, 7) but without teachers abdicating their status of 'custodians of their professionalism' (Silva 2007, 162) during their teaching career.

The expectations concerning quality teaching, capable of training active youths, necessitate high teacher qualifications (Day 2001) backed up by high professional motivation throughout a teaching career.

In order to consolidate this point, European agencies have (re)affirmed the importance of promoting quality training and teaching systems, which (cor)respond to political-social ambitions by emphasising that 'the teacher occupation should be highly qualified, based on a formative process marked by learning processes through life, a profession characterized by mobility and based on partnership working processes (Canário 2007, 3). In other words, the expectations of 'high quality teaching demand well trained, highly motivated teachers, with knowledge and capability, not only in the beginning of their career, but also throughout their professional course' (Day and Sachs 2004, 3).

\section{Portuguese education policies: recent decades}

Schools have always been influenced by the historical and cultural changes in the economic, social and political sectors of their country, which have influenced school organisation, specifically in respect to teaching and the skills and content to be taught to students.

The Portuguese Constitution of 1976 incorporates as fundamental principles the democratisation of teaching and the right to education. With the publication of the Basic Law of the Education System ${ }^{1}$ these principles are distinguished and clarified in the universality, compulsoriness and gratuitousness of education for a nine-year period of schooling (the duration of basic education). But the major innovations of this law were its reorganisation of the education system (elementary, secondary and higher) and the broadening of the concept of school, which was taken as an 
educational community belonging to a system of relationships with parents and local political bodies based on an autonomous educational project and shared by all the interested parties in the process (Afonso 1998; Correia 2000).

Although innovative elements were introduced during the 1980s which extended the concept of school, education was marked by the devaluation of democratic discourses and an investment in a referentialisation to the business world and to an economic definition of education (Correia 2000) with its 'concerns about efficacy, quality and modernisation in education' (Ferreira 2008, 136).

In this area, the study indicates that the Portuguese legislation promulgated since 2007 has exhibited a corporate and economistic ideology in its educational policies, principally when it regulates progression in a teaching career by means of a system of quotas and when it promotes a system of evaluation sustained by a bureaucratic process that instigates competitiveness and individualism. With very close objectives, other international studies have evolved that also stress the challenges and constraints of change and its implications in professional development and teacher identity (Flores, Day, and Viana 2007; Flores et al. 2009).

Stoer, Stoleroff, and Correia $(1990,11)$ noted that the education policies of the 1980 s were based on economic factors and sought to use the 'training of qualified human resources as a condition for modernisation in order to create a new tendency, which here is called vocationalism'.

In this context it has to be mentioned that - in the wake of the publication of the Basic Law for the Education System and identification of the economistic intentions of society - the issue of teacher assessment reappeared on the political agenda. The first assessment model emerged in the early 1990s (1992) and its aim was 'to strengthen the autonomy of schools and foster the professional development of teachers' (Curado 2002, 39).

The Teaching Career Statute (TCS), which was published after extremely vigorous trade union action, favoured the introduction of the most innovative element in the teaching career - the creation of a single career (Alves-Pinto 2008).

According to the author, this expression embodies a double meaning of the utmost importance: 'on the one hand, the career would not depend on the level of education but on the level of academic training; on the other hand, the single career presumes there is a career for teachers, who carry out a range of teaching functions' (Alves-Pinto 2008, 37).

With the publication of this law, performance assessment became a necessary and meaningful premise, although trade union leaders believe that its operationalisation needs to consider the kind of assessment to be applied very carefully (Alves-Pinto 2001). Following discussions between the unions and the Ministry of Education the TCS (1992) ended up containing an intrinsic form of assessment, because the assessment desired could not be a bureaucratic process. It was basically a report of what each teacher had done and, if it was made at a specific point in the transition from the 7 th to the 8 th scale, it was based on the preparation and discussion of the professional $\mathrm{CV}$ of the person in front of a panel.

Meanwhile, various evaluation reports and studies carried out on the management and administration of schools signalled the start of the legislative process that would culminate in the approval of the new regime of school autonomy, administration and management, whose 'politically expressed intention was to create and stimulate the building of initial elementary education level "schools" (Formosinho and Machado 2000, 52), because the pre-school and first elementary education 
establishments amounted to what was described as 'a scattered fragmentary network of units', thanks to the Regional Education Offices being for many years 'the final link' in the connection to the schools.

The approval of the Legislative Order, which led to the creation of groupings or 'schools' 'as organisational units of a reasonably human size, having their own administration and management, making decisions and acting autonomously' (Formosinho and Machado 2000, 52), was followed in the next year by the Decree Law no. 115-A/98 of 4 May and meant that this strategy was automatically boosted. This initially led to the creation of a lot of horizontal groupings (vertical ones came later) in Portugal.

Schools thus took the first steps of their lives on their own initiative in the educational community by taking as their first referential the participation of parents and the local authority. This community experience, which was expressed in school autonomy, entailed a great deal of responsibility for the 'local actors' (Formosinho and Ferreira 2000, 83), because they were now accountable for their actions.

Projects to reorganise the elementary education curriculum were implemented 'with a view to reinforcing the interaction of the three cycles of schooling involved at both the curriculum level and in terms of organising monitoring and induction processes to ensure, without loss of the relevant identities and objectives, higher quality learning' (Departamento de Ensino Básico 2001).

This quality of learning particularly focused on the discussion and construction of a curriculum that came to be seen 'as a corpus of learning that everyone must achieve at school, a set of opportunities for personal development, an integrating and distinguishing area, a dynamic construction that ought to result in the participation of all the parties in the education process' in an effort to finally replace the view of the curriculum as a set of fragmented subjects and content (Morgado and Carvalho 2004, 93).

The law under discussion has now been amended to produce another one (2011) designed to optimise resources and reduce the weekly lesson load for students by cutting out the 'project' area from the list of non-subject curriculum options and placing more emphasis on supervised study so as to encourage autonomy and improve school outcomes. The intentions of this law are obviously being contested by the teachers, who are backed by the unions, because they once again disagree that the economic woes of the country should obstruct the course of education and hamper the adoption of high-quality education.

This conception and publication of legislation by governments to impose targets on teachers regardless of the culture and context of the educational contexts has been hotly opposed in schools, thus preventing teachers from developing professionally and significant changes from being introduced (Pacheco 2002), as the latter remain 'in the field of expectations that they have generated' (Morgado 2005, 76).

The upheaval and conflict in the world of education continued throughout the last decade and reached its peak in 2007, when the Ministry of Education, which was unmoved by the theoretical considerations of experts in education, reformulated the Teaching Career Statute (2007) and regulated the teacher assessment process (2011) based on the policy of the 'need for change' without any preparation of the educational contexts.

The education policies at the time announced the need to raise the standard of teaching and improve the quality of student learning, which was basically supported 
by the quality of the performance of the teacher - agreed in terms of teaching merit, as a motivating premise for professional development and career advancement.

So the unrest, challenge and resistance of the teachers to the changes has lasted, on the whole, until 2011, thus forcing the Ministry of Education to undertake a series of revisions of the TCS in response to the climate of malaise and inability to establish conditions favourable to the implementation of the assessment process in schools.

After yet another (re)appraisal of the various stages of the assessment process and particularly the most fiercely contested ones, the Ministry of Education decided to simplify the TCS to make it easier to apply.

The government officials responsible for the process resumed contacts with the trade unions and this led to a Memorandum of Understanding that gave rise to a simplified version of the teaching performance assessment procedure (2008), which was aimed at those teachers who required assessment in order to progress in their career or to renew contracts in the next academic year.

The process was again simplified in 2009 in the wake of a series of protests by teachers and their unions that were largely prompted by the bureaucratic burden the process implied. This time certain assessment parameters were removed from the TCS including educational results and drop-out rates.

After three years of constant strife (2008 to 2010) with the Ministry of Education, teachers and unions finally saw equality between teachers restored, thus putting an end to categorising them as 'classroom teachers' and 'senior teachers' and so a single category for the teacher career structure was reinstated (2010).

The principles governing the change in the Teaching Career Statute were established by Regulatory Order No. 2/2010 of 23 June 2010. The criteria of rigour and appreciation of professional merit were maintained and it was established that performance assessment should be carried out under simplified procedures with the rapporteur ${ }^{2}$ monitoring the performance of the teacher under assessment and permanently interacting with him/her.

But more legislation has been passed very recently to account for an assessment process that - from the very start - was clearly unsuited to the Portuguese educational contexts. Its implementation on the ground remains dubious, regardless of it being patched up, and this is creating significant and widespread mistrust in those most directly affected by the assessment process - the teachers.

\section{The professional development of teachers in school}

The consolidation of the right to education that has led to the appearance of educational communities, whose characteristics are heterogenic and changeable and which have implications for the need to coordinate the action of teachers, has paved the way for discussion about and consideration of schools and their main actors.

These circumstances have led to a new conception of professional performance based on strategies that can ally quality of teaching with quality of learning (Morais and Medeiros 2007), thus leaving no alternative but to review attitudes, conceptions and methods and to create a climate of professional development within the school.

In terms of education, the term professional development is often confused with or replaced by continuous training. However, based on research by Garcia (1999, 136), it is believed that professional development 'has a connotation of evolution and continuity', which also presumes 'an approach to teacher training that values its 
contextual [and organisational] nature', while it overcomes the 'traditional juxtaposition of initial training and teacher development' (137). Meanwhile continuous training is taken to be an ongoing and permanent process designed to improve development (Pacheco 1995) and, therefore, it is experienced and felt as 'an active project, engaged in at the rate of the situation that makes it live' (Malglaive 1995, 24).

Oliveira-Formosinho $(2009,225)$ stated that professional development 'is a more experiential and more integrated process', thus steadily moving away from the purely individual aspect towards valuing development in context.

The emotional component of work, as pointed out by Silva $(2007,159)$, 'is an important factor, which frequently influences the actions and emotions of professionals in their performance and, above all, in the way they carry out their profession'.

The works of Day $(2001,2004)$ confirm this influence, because they refer to the interaction of the different professional experiences of teachers like the contexts in which they work - from the classroom to the school and on to social and political contexts - that give rise to the thoughts and actions of teachers and in this way conditioning the attitudes of teachers in view of the necessity for professional development.

Yet in the opinion of the same author, in order to improve the performance of teachers, their development must be defined in accordance with their personal and institutional needs so as to favour their 'commitment and disposition in relation to learning', while being a learner throughout life (Day 2004, 186).

In the words of Dean (1991), professional development suggests a process whereby teachers become more professional. So professional development can be seen as growing in certain aspects of professionalism and can be legitimately applied to the development of a teacher or group of teachers in the work context, where the emphasis is on reflection (Herdeiro 2010).

School-centred professional development, therefore, implies extra responsibilities for the institution, so as to ensure that the individual needs of teachers are much more closely met. Herdeiro says that teachers will develop better professionally, if the school backs them, and the school itself will develop, if the working environment and national education policies support it. She thus values mutual support as a fundamental part of the development process.

In terms of human promotion, studies by Bell and Gilbert (1996) stress the professional development in changing schools, because they believe it implies both the use of different teaching activities and the development of the convictions and conceptions that underlie such activities.

Teachers, by adopting a learning attitude from the start of their career that lasts until they retire, choose professional development as a learning process not as a remedial one (Morais and Medeiros 2007) nor as something that happens simply as a result of spending a certain number of years in teaching (Dean 1991).

Morais and Medeiros (2007) added that the most important part of professional development 'is the broadening and self-development of professional knowledge' (33), thereby valuing essential premises like teachers knowing their individual mental structures and the thinking that influences their actions/attitudes in the classroom and peer relationships.

According to the line of research of Day (2001), it can be seen that the interaction of various professional experiences that happen during their teaching life within 
the contexts in which they work - from the classroom and school to the social and political contexts - derives from the reflection and action of teachers. This conditions their attitudes towards the need for professional development.

For Morais and Medeiros (2007, 35), the professional development initiatives promoted by school groupings and/or training centres should help teachers to 'acquire and develop teaching strategies and techniques, which may effectively promote the active construction of the meaning of student learning and its self-regulation'.

The guidelines for professional development in schools outlined by Day and Sachs (2004) were important for their useful suggestions, which include: i) identifying the agendas of teachers for learning and change; ii) realising that the learning of teachers needs to focus on personal, sustained, individual and collaborative investigation - both in school and outside - and iii) understanding that professional development means a set of opportunities appropriate to needs and purposes.

Inherent to these guidelines must be the goals of those who conceive education. Essentially they should be concerned to ensure that the projects/programmes offered to schools match the opportunities for suitable professional development in order to meet professional needs (Flores et al. 2009). According to Sachs (2009, 114), this purpose shows that 'professional development must be differentiated in the same way that learning should be differentiated for students', so that it is useful.

But for this to happen, Sugrue $(2004,85)$ thought that teachers should start by controlling their learning process so that - in an 'external climate that affects the contexts of various forms' - it can obtain answers appropriate to the challenges it faces. The author also believed that learning 'is a delicate step in the career that requires time and room, as well as conditions' (85), so that continuous teacher professional development may be 'a means of maintaining and sustaining a competent teaching profession' (Sachs 2009, 116).

So one may ask: Does the latest legislation passed in Portugal stimulate the professional development of teachers in schools? Or: Does it help to reinforce the factors that inhibit their professional development?

Work by Garcia $(1999,193)$ refers to a series of factors that influence the process of the professional development of teachers, by noting that it is subject to 'influences and pressures from several official and extra-official, professional and extra-professional, bodies'. The author says that the processes are clearly determined: a) by the education policy of the day, which is based on matters related to the curriculum and the organisation and function of schools; b) by the curriculum model that establishes the training needs of teachers; c) by the organisational structure of the institutions charged with planning and developing professional development activities; d) by the organisational culture of schools; e) by the teachers themselves - both individually and collectively; and, f) by the social forces that cover the conceptions of parents with respect to teaching and schools.

However, in times of change the politicians in charge must anticipate the existence of the factors involved in the work context - time, bureaucratic work, intensity of work - that can discourage or encourage the processes of the professional development of the teacher (Apple and Jungck 1992; Hargreaves 1998; Machado and Formosinho 2009).

Yet two years before the carrying out of this particular research in Portugal Flores, Day, and Viana (2007) were interested in analysing and understanding the way(s) how teachers (Portuguese and English) viewed the (curricular) changes 
occurring in teaching, as well as their effects on the way they faced their professionalism and professional identity(ies).

This study recalls that in 2004, Portuguese teachers felt satisfied and determined in their educational tasks. In contrast English teachers, due to the reforms imposed at that time, stated that they were dissatisfied and had little commitment and, when questioned about their working conditions, their pessimism was even more significant. The increase in the volume of work after class time, the recognition that bureaucracy in teaching has grown and the innovations imposed have all contributed towards professional demotivation with its impact on identity.

Recently, a further international study by Flores et al. (2009) was undertaken with the central purpose of understanding the motivations for and constraints affecting the professional development of the teacher. This study, among other aspects, focuses on the set of factors considered to inhibit professional development. They included social factors (the economic crisis and the devaluation of the teaching profession), factors linked to the educational system (legislative instability and excessive bureaucracy), factors related with scholastic organisation (absence of strong leadership, overloading of activities and increasing bureaucracy) and personal factors (professional demotivation), which clearly appear to be preponderant in the process of teacher development.

Through the theoretical contextualisation and the content of current education and curriculum policies in Portugal, it is wholly pertinent to mention the perceptions of elementary school teachers with respect to the main factors that hamper their professional development in school: competition and individualism; the escalation of tasks; excessive red tape; and professional demoralisation.

\section{Methodology}

The reference for this study was the contextualisation outlined briefly above in order to undertake the research project with elementary school teachers. Some of the results are presented in this paper. The main purpose was to identify the elements involved in teacher professional development and the implications that recently passed legislation has for professional development in the school and the quality of teaching.

Among the goals of this research are those that interact most directly with the outcomes presented and discussed here, namely i) to identify the views of elementary school teachers on the recently passed legislation; ii) to learn the impact of the laws on teacher professional development; and iii) to examine the factors that inhibit the quality of teaching.

Thus, the authors chose to combine quantitative and qualitative research approaches for the study. According to Ghiglione and Matalon (1992) the quantitative and qualitative approaches complement one another by enabling the data to be considered in greater depth, despite differences raised with respect to their application in the research field.

The qualitative approach involved collection of the biographical narratives of the elementary school teachers, which embraced the two perspectives that Bertaux (1997) indicated as being particularly significant. These are: 'As a form of knowing' - when access to knowledge is achieved by asking for a record of experiences undergone in relation to recent legislation and its impact on their professional development; and, 'as a form of communication' - because it is through conversation 
and writing that the people in the study managed to convey their experiences expressively. This provided the study with valuable individual meanings which, after comparison, enabled the authors to move from the particular to the general.

In 2008 in Phase One, in the eight elementary school teachers recounted their perceptions after the TCS and Teacher Performance Evaluation (TPE) laws that had been published with respect to the implications for the (re)construction of identity (ies), for their career and for professional development.

In Phase Two in 2009 a questionnaire was designed. It contained closed and open questions and Likert scales and was based on the outcomes of the narratives, the legislation and a literature review. It was sent out to 396 elementary school teachers who were working in the same schools as the eight teachers whose accounts had been collected. This was the sample.

The questionnaire was returned by $63 \%$ of the teachers (i.e. 249 of the total) and these were then processed and analysed with the SPSS programme (Statistical Package for the Social Sciences), version 17.0.

In 2010 in Phrase Three, once the teachers who had volunteered to participate in this phase had completed the questionnaire, they were put into one of the three discussion groups that were formed to identify the internal aspects of the issues under discussion about subjectivities shared and assimilated by the group in order to construct their own discourse in the context. Later on in this phase the key eight informants were again asked to give an oral account of their perceptions and experiences in school in recent years.

The operationalisation of the phases enabled the authors to get useful information - almost to saturation point - to obtain valid responses to the research questions, i.e. information that ensured the comprehension and appreciation of the voices and feelings of the teachers in their professional practice in the light of recent changes in education.

In this article, the results of data processing and qualitative analysis on the previously identified bases will be pointed out.

\section{Characteristics of the sample}

Of our sample it should be noted that the eight elementary school teachers have been in contact with the authors since other research was undertaken in 2006/2007 and that they have been hugely important in giving information very easily, because they have real knowledge of the events and because of their willingness to impart this knowledge in a spirit of constant cooperation.

These teachers are still our 'key informants' (Rodríguez Gómez, Gil Flores, and García Jiménez 1999, 127), especially in Phases One and Three of the study. Their relevant personal and professional details are displayed in Table 1.

Of the 249 respondents to the questionnaire, $80.7 \%$ were female and $19.3 \%$ male, which signifies the predominance of women teachers in the groupings surveyed. In terms of age, they were mainly in the 31 to 40 age group (39.0\%) and in the 41 to 50 age group $(30.5 \%)$.

In terms of education, $85.1 \%$ of the teachers had first degrees (licentiates), $5.6 \%$ had already shown a personal/professional interest in taking a Master's degree and $8.8 \%$ had the qualification provided by their initial training (Bachelor's degree).

Most of the teachers $(48.2 \%)$ were in an insecure professional situation, because they were still under contract. The teachers with the most professional experience 
Table 1. Characteristics of the eight key teachers.

\begin{tabular}{|c|c|c|c|c|c|c|}
\hline \multirow{2}{*}{ Teacher } & \multicolumn{6}{|c|}{ Characteristics } \\
\hline & $\begin{array}{l}\text { Grouping } \\
\text { (Vertical) } \\
\end{array}$ & Age & $\begin{array}{l}\text { Length } \\
\text { of } \\
\text { service }\end{array}$ & Category & Duties & Education \\
\hline Sónia & $\mathrm{B}$ & 36 & 14 & Teacher & Establishment coordinator & First degree \\
\hline Patrícia & $\mathrm{C}$ & 39 & 13 & Teacher & & First degree \\
\hline Amélia & G & 47 & 21 & $\begin{array}{l}\text { Senior } \\
\text { teacher }\end{array}$ & Establishment coordinator & First degree \\
\hline Carolina & E & 39 & 14 & Teacher & - & First degree \\
\hline Elsa & $\mathrm{D}$ & 39 & 13 & Teacher & Establishment coordinator & $\begin{array}{l}\text { Master's } \\
\text { degree }\end{array}$ \\
\hline Catarina & $\mathrm{F}$ & 38 & 13 & Teacher & Establishment coordinator & First degree \\
\hline Diogo & A & 53 & 27 & $\begin{array}{l}\text { Senior } \\
\text { teacher }\end{array}$ & Year coordinator & First degree \\
\hline Gabriela & $\mathrm{H}$ & 43 & 22 & $\begin{array}{l}\text { Senior } \\
\text { teacher }\end{array}$ & $\begin{array}{l}\text { Coordinator of Teachers' } \\
\text { Council }\end{array}$ & First degree \\
\hline
\end{tabular}

in the Grouping Table and Pedagogical Area - the permanent or established teachers - amounted to $51.9 \%$, thereby balancing the percentage of teachers under contract.

Finally, another significant figure characterising the respondents is length of service with the highest percentage being those with less than 10 years of service in teaching (37.8\%). Next highest was the percentage with 11 to 20 years of service, $30.9 \%$.

Teachers with up to 20 years of service $(68.7 \%)$ were a well-established group in terms of career and professional experience.

After this brief description of the sample, the longitudinal nature of the research should be stressed. This aspect makes it somewhat unusual among studies that investigate the experiences of teachers with respect to how they develop and perceive themselves over their professional career.

This article will explain the perceptions of the elementary school teachers as recounted in written and oral biographical narratives collected in the two phases mentioned above and in the three discussion groups set up for the purpose.

Besides the perceptions reported in the narrative texts of the teachers some of the results collected from the application of a questionnaire distributed to 396 teachers of the First Cycle of Basic Education will be presented as well as a statistical analysis carried out with chi-squared and $t$-tests.

\section{Some research results: factors impeding the quality of teaching and professional development}

\section{Competition and professional individualism}

Currently, teachers feel that a professional and personal relationship sustained in the competitiveness causes conflicts among teachers, as was reported below: 
I've noticed a certain rivalry and I see that people, when they do something that they even think that it's, that it's good, that has results, that leads to people making progress and they notice, they try to hide it. (Patrícia, oral narrative 2010)

because, I'm the one who's going to benefit from my assessment... and worse, I'll gain advantage from my assessment if the others don't, because if I stand out from my colleagues, I'm going to benefit. (Mário, Discussion Group [DG] 2)

So the philosophy of the new model of teacher evaluation gave rise in the teachers to competitive and individualistic tendencies. They constructed didactic and pedagogical materials that they considered innovative but avoided sharing them with their peers.

Competition is an acquired reason that this culture chooses to strengthen. There is less care about the professional goals of others and teamwork in school is ignored, which inevitably ruins all the efforts that have been made in schools to sustain teaching as a relationship of collaboration, as teachers explain:

This is no good, it's terrible, it's not bad, it's appalling, it means that I'm getting ready to stride ahead of all my colleagues. (Mário, DG2)

They don't share, or if they do it's a lot later, so that someone will know that it was their work, and I'm not used to this, I've come from somewhere where this didn't happen, where teamwork really was the norm. (Catarina, oral narrative 2010)

So teachers are 'shutting themselves into their own world' and forgetting about the others, choosing the times to show themselves publicly, which is preferably when their superiors are around in order to please them and show that they are doing different things and doing them better than the others, thus believing that they shine in the group, as was mentioned:

And people are starting to close up, I mean they show something as a good result, but don't tell you anything else, really so that you won't do the same. (Patrícia, oral narrative 2010)

Teachers like to be noticed for new things when their superiors are around. (Elsa, written narrative 2008)

the people who do well are those who do really nice things, I think that's it, I really think that's it. (Moura, DG1)

According to the voices of the participant teachers, the principal reason for a teacher showing a different teaching practice from the others falls back on the necessity of providing evidence, and preferably in the presence of their superiors with the aim of pleasing them and to obtain a more positive and possibly higher evaluation.

In a competitive environment, it is rare to find teachers helping one another, since they are fighting for their own objectives to get the advantage, the reward or the position they will need to obtain a 'Very Good' or 'Excellent' rating on their performance assessment, related to the coordination of a project, for instance. Thus they please the parents of the students and show indifference to the (negative) 
consequences that can affect the teaching body, even if this type of relationship does nothing for teaching professionalism:

we're looking to see who's doing nice things in the classroom. (Camila, DG2)

with my colleagues there's a lot of interest in wanting to be better, mostly with the parents, showing more. (Ana, DG1)

not being synonymous with a good professional. (Questionnaire [Q] 106)

So the culture of teaching competitiveness leads to the reinforcement of an individualist culture, thereby discouraging a collaborative culture based on sharing and a spirit of solidarity found in some schools which, finally, once again fell into the realm of individualism, as Diogo says:

sharing, the spirit of solidarity, not now common in schools, apart from exceptions that break the mould, they've definitively descended into individual kingdoms. (Diogo, written narrative 2008)

In the perception of the teachers, individualism is linked to defensive behaviour, to mistrust and professional anxiety, as they stated:

mistrusting everything and everyone, it seems that there's always someone that wants to intrigue against us. (Amélia, written narrative 2008)

This kind of assessment does nothing to improve a teacher's performance, since it creates a great deal of anxiety in a teacher. (Q 56)

Through the complicated and constraining situation existing in schools today, individualism is seen not as a personal failing of the teacher but as induced by the conditions in the workplace that requires an organisation of priorities:

will [the assessment model] conversely contribute to the emergence of a selfish and competitive professional culture that is demoralising and inspires insecurity? (Carolina, written narrative 2008)

people shut themselves off a lot, spend a lot of time on themselves. (Catarina, oral narrative 2010)

In this way, as a consequence of the new rules imposed by Portuguese legislation, the teachers participating in this study felt difficulties in creating and maintaining collaborative environments in school that promote teacher learning and professional development.

\section{Intensification of teachers' work}

The teachers taking part in this research felt that they were being seriously overloaded with tasks: they had more responsibilities, were more accountable and needed to struggle with a wide range of skills in and out of the classroom. It was 
hard and affected the teaching role, because far too many demands were made in school, as they mentioned:

This change tried to place more responsibility on schools and teachers. (Elsa, written narrative 2008)

we've got so many things to run there, from behaviour. (Fátima, DG3)

I feel that my job has been made harder. (Catarina, written narrative 2008)

my teaching work may be affected; there are so many demands. (Elsa, written narrative 2008)

These expressions revealed professional preoccupation and discontent, as a consequence of the manifold tasks that they were called upon to do as teachers, namely bureaucratic and administrative tasks which reduced their availability to devote to pedagogical practice.

Furthermore, teachers were forced to tackle administrative assessment tasks and supervision and educational guidance in schools. They spent a great deal of time on guidance and/or attending meetings of all kinds - of teachers, year coordination, parents and guardians, management, school coordination and teacher assessment, not to mention informal meetings, which left them little time for useful work in the classroom or time for themselves (as a person and a professional) and their families, as the participants made clear:

teachers' activity is so taken up that most of the planning, support materials for classes, organisation of files, reports, preparation for meetings ... is done at home. (Gabriela, written narrative 2008)

they really prejudice actual teaching because the teacher has countless parallel duties as well as teaching. (Manuel, DG1)

in addition to being, to having a class, I'm the establishment coordinator too ... and I'm feeling a bit lost at the moment. I'm not managing to reconcile the two jobs, as establishment coordinator requires a lot from me ... the class is suffering because I'm doing the other job. (Catarina, oral narrative 2010)

So teachers saw this job overload as a factor that hampered professional development with consequential adverse effects on the student teaching and learning process and on professional identity.

\section{Too much bureaucracy}

The teachers think these education policies are inappropriate, as they lack recognition from the authorities in charge of the groupings and the education community and as they also prevent good pedagogical practice in the classroom, because of the inordinate amount of time spent discussing bureaucratic issues at the so-called pedagogical meetings. 
The more effort we make to try to improve the way we teach and to see that the students learn, the more we're criticised or observed. (Q 146)

The bureaucracy that's forced on schools at the moment means that teachers are asked to do far too much work. (Q 7)

Being a teacher is being a man of papers, red tape and abandoning the students. (Q 10)

we're drowning in bureaucracy. That's not been mentioned yet here, loads of red tape and then we go to meetings to deal with more of it, because information comes from the pedagogical council, goes to the meeting, information associated with the bureaucracy. (Moura, DG1)

Overall, the elementary school teachers found the reformulation of the TCS especially the performance assessment model - to be a policy that had a negative impact on the their conceptions regarding their development with particular emphasis on excessive bureaucracy. This discontent was evidenced by $65.5 \%$ of the teachers in this study and applied especially to the statement that schools/ school groupings are subjected to constant legislative attack and $92.8 \%$ of the teachers said that this naturally leads to too much red tape in the school, which strips the teaching profession of its character, since its chief function, namely teaching, is being forgotten.

\section{Lack of professional motivation}

At the conference on the professional development of teachers organised during the Portuguese Presidency of the Council of the European Union, Canário (2007) underscored the importance of motivating teachers professionally, as an alternative to fighting the increasing complexity of the profession, which corresponds (as has been said before) to more paperwork, fresh demands and an expansion of the profile of its professional mission.

The lack of motivation for profitable teacher development is basically due to the extra demands made on teachers in the workplace, the lack of recognition and comprehension of their social contexts and particularly government responsibility, as the following observations by the teachers show:

Given the situation with respect to current education policy, I think that what teachers actually do is not recognised, and is sometimes undervalued, which makes me feel discouraged and dissatisfied. (Q 18)

This situation causes teachers to feel discouraged and this is inevitably reflected in their work. (Elsa, written narrative 2008)

The climate of tension and discord in schools is such that it's become impossible to foster motivation and self-esteem. (Patrícia, written narrative 2008)

At present, in professional terms, I feel discouraged, dissatisfied, because of the way society now sees teachers. (Q 141) 
It is believed that the latest changes and widespread criticism of the work of teachers are the main reasons for the problems in the education system and this has led to significant teaching malaise in schools.

When the elementary school teachers were asked if they felt motivated and satisfied in their daily work - given the policy implemented in their country - the teachers stated that the recent legislation (TCS and ETP) intervened negatively in their professional motivation $(62.6 \%)$ by jeopardising the quality of their teaching work in the school context.

The absence of motivation for developing useful teaching work shown in Table 2 resulted essentially from the growing demands on their teaching activity and from a lack of recognition and understanding of the social contexts.

The teachers taking part in this study were frustrated and tired, which led to a lack of motivation and an inability (largely because of too little time and too much red tape) to meet all the demands made of them without jeopardising student learning.

This is what is happening in teaching at the moment with all the damaging consequences that this entails for the professional development of teachers, which may lead to uninspired teaching lacking quality.

\section{New professionalism and quality of education: subversion or challenge?}

Given the need to respond to the increase in complexity and to the constant changes of present-day society, teachers find themselves constrained to transform their professional roles and adapt themselves to new working contexts on behalf of a new professionalism. Besides the need to adapt to new working contexts, teachers understand that the political decisions, which have been taken in a perspective of higher accountability in accordance with a performance-oriented and managerial logic, result from the concern of governments to promote teaching quality and, therefore, to improve the school results of students, as other research studies have demonstrated (Flores 2010).

Quite recently, Day and Gu (2010) have noted that a problematic educational structure that results from the need for teachers to perform other functions in addition to the ones for which they consider themselves responsible, as professional educators, contributes to the emergence of new teaching contexts and new professional lives.

Table 2. The demotivation of teachers in relation to recent legislation with impact on their socio-professional identity (in percentages).

\begin{tabular}{|c|c|c|c|c|}
\hline Indicators & & Positive & Negative & CST \\
\hline $\begin{array}{l}\text { Do you feel professionally motivated? } \\
\text { Do you feel that the new Statute for the Teaching } \\
\text { Career and evaluation of performance boosts } \\
\text { your professional development? }\end{array}$ & & $\begin{array}{r}37.4 \\
4.5\end{array}$ & $\begin{array}{l}62.6 \\
95.5\end{array}$ & $\begin{array}{r}15.6^{* * *} \\
204.0^{* * *}\end{array}$ \\
\hline Indicators & Positive & Neutral & Negative & CST \\
\hline $\begin{array}{l}\text { In which way does the evaluation of teaching } \\
\text { performance influence your professional attitude } \\
\text { in school? }\end{array}$ & 4.5 & 53.8 & 41.7 & $98.2^{* * *}$ \\
\hline
\end{tabular}

Note: ${ }^{* * *} p<0.001$ and CST $=$ Chi-Square Test. 
In a perspective of quality teaching the authors claim it is important to warn political decision makers - both inside and outside school - of the need to attend to certain elements, which are considered to be central for teacher motivation and (good) performance, namely the commitment to teaching work, physical and social working conditions of teachers, the influence of certain events in the life of teachers and professional and organisational relationships (Day and $\mathrm{Gu} 2010$ ).

In this context, the present situation of teachers in school can be understood much better if one considers it in the school and in the social context in which they work, so that it is possible to perceive the resurgence of cultures like individualism and the birth of others such as professional competition.

In school not only have teachers gradually got to the stage of being controlled by prescribed programmes and compulsory curricula but they have seen their job become more intense and bureaucratic. They are required to respond immediately to pressure and, above all, they have conformed to multiple innovations in conditions that are all too often controversial.

Teachers see professional development as a route to gaining new knowledge and skills but their experience in school suggests that there is no interest in motivating them to develop their teaching practice. Indeed, one can see the entrenchment of professional disenchantment that goes back to 2007, which drags with it the discrediting of the profession and social disrespect, which affect the identity of the teacher.

In order to reinforce these conclusions, Flores et al. (2009) in their recent studies mentioned that the conditions which characterise teaching nowadays affect not only pedagogical practice but also the learning and development of teachers in their working context.

Flores et al. (2009), therefore, question whether the present educational situation, caused by recent Portuguese legislation (TCS and ETP), promotes teaching quality and professional development or whether it fosters professional demotivation, the 'resurgence' of cultures, such as individualism, and the 'birth' of others, such as competition, which inevitably lead to the degradation of professional relationships and contextual cultures considered to be essential in teaching work.

In this context, the success of students will be safeguarded if the teacher accepts the responsibility of critically reflecting on his/her own action in order to (re)direct it towards improvement, if he/she accepts the autonomy of the educational process and recognises the importance of group work and professional relationships for educational practice.

However, in the opinion of Alves and Flores $(2010,9)$ 'the fragility of teacher professional status does not mobilise towards these responsibilities', which is an aspect that our research also sustains.

\section{Notes}

1. Law No. $46 / 86$ of 14 October 1976 .

2. The rapporteur is the member of the assessment panel responsible for monitoring the professional development process of the assessed teacher with whom they remain in permanent interaction, so as to enhance the training aspect of performance assessment. 


\section{Notes on contributors}

Rosalinda Herdeiro received her $\mathrm{PhD}$ in Sciences of Education and is an elementary school teacher. Her research work focuses on the area of curriculum studies, specifically on the professional development and identities.

Ana Maria Silva has a $\mathrm{PhD}$ in Education and she is professor and researcher at the Institute of Education at the University of Minho (Portugal). Her research work and teaching focus on the area of curriculum studies, specifically on the socio-professional knowledge and identities.

\section{References}

Afonso, A. 1998. Políticas educativas e avaliação educacional: uma análise sociológica (1985-1995). Braga: Universidade do Minho.

Alves, M. P., and M. A. Flores. 2010. "Introduction." In Trabalho docente, Formação e Avaliação. Clarificar Conceitos, Fundamentar Práticas, edited by M. P. Alves and M. A. Flores, 7-15. Porto: Edições Pedago.

Alves-Pinto, C. 2001. "Socialização e Identidades Docentes." In Ser Professor No Limiar Do Século XXI, edited by M. Teixeira, 19-80. Porto: Edições ISET.

Alves-Pinto, C. 2008. "Socializações Docentes e Desafios da Mudança da Escola." In Políticas Educativas e Conhecimento Profissional: A Educação e a Enfermagem em reestruturação, edited by J. Ávila de Lima and H. Rocha Pereira, 135-151. Porto: Livpsic.

Apple, M., and S. Jungck. 1992. "You Don't Have to Be a Teacher to Teach This Unit: Teaching, Technology and Control in the Classroom." In Understanding Teacher Development, edited by A. Hargreaves and M. Fullan, 20-42. New York: Teachers College Press.

Ball, S. J. 2002. "Reformar Escolas/Reformar Professores e Os Terrores da Performatividade." Revista Portuguesa de Educação 15 (2): 3-23.

Bell, B., and J. Gilbert. 1996. Teacher Development. A Model from Science Education. London: Falmer Press.

Bertaux, D. 1997. Les Récits de Vie. Paris: Nathan.

Caetano, A. P. 2007. "A Complexidade da Mudança e da Formação - Uma Perspectiva de Religação e Diálogo." In Profissionalismo Docente em Transição: As Identidades dos Professores em tempos de Mudança, edited by M. A. Flores and I. C. Viana, 103-108. Braga: Universidade do Minho, Cadernos CIED.

Canário, R. 2007. "Formação e Desenvolvimento Profissional Dos Professores." In Do Conselho da União Europeia, Conferência Desenvolvimento Profissional de Professores Para a Qualidade e Para a Equidade da Aprendizagem Ao Longo da Vida, edited by Presidência Portuguesa. Lisbon: Ministério de Educação.

Correia, J. A. 2000. As Ideologias Educativas em Portugal Nos Últimos 25 Anos. Porto: Edições Asa.

Curado, A. P. 2002. Política de avaliação de professores em Portugal: Um Estudo de Implementação. Lisbon: Fundação Calouste Gulbenkian.

Darling-Hammond, L. 2010. "Reconhecer e Potenciar a Eficácia Docente: Guia Para Decisores Políticos." In A Avaliação de Professores Numa Perspectiva Internacional. Sentidos e Implicações, edited by M. A. Flores, 197-235. Porto: Areal Editores.

Day, C. 2001. Desenvolvimento Profissional de Professores. Os Desafios da Aprendizagem Permanente. Porto: Porto Editora.

Day, C. 2004. A Paixão Pelo Ensino. Porto: Porto Editora.

Day, C., and Q. Gu. 2010. The New Lives of Teachers. London: Routledge.

Day, C., and J. Sachs. 2004. "Professionalism, Performativity and Empowerment: Discourses in the Politics and Purposes of Continuing Professional Development." In International Handbook on the Continuing of Teachers, edited by C. Day and S. Sachs. 3-31. Maidenhead: Open University Press.

Dean, J. 1991. Professional Development in School. Milton Keynes: Open University Press.

Departamento de Ensino Básico. 2001. Princípios, Medidas e Implicações. Lisbon: Ministério da Educação. 
Ferreira, E. 2008. "Políticas Educativas, Governação Democrática E Autonomias.” In Políticas Educativas E Dinâmicas Curriculares Em Portugal E no Brasil, edited by A. C. Lopes and C. Leite, 135-52. Porto: Livpsic.

Flores, M. A., C. Day, and I. C. Viana. 2007. "Profissionalismo Docente Em Transição: as Identidades Dos Professores Em Tempos de Mudança: Um Estudo Com professores Portugueses E Ingleses." In Profissionalismo Docente Em Transição: As Identidades Dos Professores Em Tempos de Mudança, edited by M. A. Flores and I. C. Viana, 7-45. Braga: Universidade do Minho, Cadernos CIED.

Flores, M. A., A. M. Veiga Simão, R. Rajala, and A. Tornberg. 2009. "Possibilidades e Desafios da aprendizagem em contexto de trabalho: Um estudo internacional." In Aprendizagem e Desenvolvimento Profissional de Professores: Contextos e Perspectivas, edited by M. A. Flores and A. M. Veiga Simão, 119-51. Mangualde: Edições Pedago.

Flores, M. A. 2010. "Introduction." In A Avaliação de Professores Numa Perspectiva Internacional: Sentidos e Implicações, edited by M. A. Flores, 6-21. Porto: Areal Editores.

Formosinho, J., and F. I. Ferreira. 2000. "O Pragmatismo Burocrático. Um Contributo Para o Estudo da Política Educativa no Quotidiano." In Politicas Educativas e Autonomia das Escolas, edited by J. Formosinho, F. Ferreira, and J. Machado, 77-90. Porto: Edições ASA.

Formosinho, J., and J. Machado. 2000. "A Administração das Escolas no Portugal democrático." In Politicas Educativas e Autonomia das Escolas, edited by J. Formosinho, F. Ferreira, and J. Machado, 31-56. Porto: Edições ASA.

Garcia, C. M. 1999. Formação de professores: Para Uma Mudança Educativa. Porto: Porto Editora.

Ghiglione, R., and B. Matalon. 1992. O Inquérito: Teoria e Prática. Oeiras: Celta Editora.

Goodson, I. 2008. Conhecimento e Vida Profissional. Estudos sobre educação e mudança. Porto: Porto Editora.

Hargreaves, A. 1998. Os Professores em Tempos de Mudança. O Trabalho e a Cultura dos Professores na Idade Pós-Moderna. Lisbon: McGraw-Hill.

Herdeiro, R. 2010. Trabalho Docente e Desenvolvimento Profissional: Narrativas de professores. Lisbon: Chiado Editora.

Hill, P. 2010. "Large-Scale Assessment for Accountability Purposes." In Second International Handbook of Educational Change. Part 1, edited by A. Hargreaves, A. Lieberman, M. Fullan, and D. Hopkins, 415-444. London: Springer Science+Business Media.

Machado, J., and J. Formosinho. 2009. "Professores, Escolar e Formação. Políticas e Práticas de Formação Contínua." In Formação de Professores, edited by J. Formosinho, 287302. Porto: Porto Editora.

Malglaive, G. 1995. Ensinar Adultos: Trabalho e Pedagogia. Porto: Porto Editora.

Morais, F., and T. Medeiros. 2007. Desenvolvimento Profissional do Professor. A Chave Do Problema? Azores: University of Azores.

Morgado, J. C. 2005. Currículo e Profissionalidade Docente. Porto: Porto Editora.

Morgado, J. C., and A. A. Carvalho. 2004. "Usufruir das Mudanças Curriculares Para Uma Integração das Tecnologias da Informação e Comunicação." Revista de Estudos Curriculares 2 (1): 85-120.

Oliveira-Formosinho, J. 2009. "Desenvolvimento profissional dos professores." In Formação de Professores. Aprendizagem profissional e acção docente, edited by J. Formosinho, 221-284. Porto: Porto Editora.

Pacheco, J. A. 1995. Formação de Professores: Teoria e Praxis. Braga: Universidade do Minho.

Pacheco, J. A. 2002. Políticas Curriculares. Porto: Porto Editora.

Rodríguez Gómez, G., J. Gil Flores, and E. García Jiménez. 1999. Metodologia de la Investigación Cualitativa. Málaga: Edicones ALJIBE.

Sachs, J. 2009. "Aprender Para Melhorar ou Melhorar a Aprendizagem: O Dilema de Desenvolvimento Profissional Contínuo dos Professores." In Aprendizagem e Desenvolvimento Profissional de Professores: Contextos e Perspectivas, edited by M. A. Flores and A. M. Veiga Simão, 99-118. Mangualde: Edições Pedago.

Silva, A. M. 2007. "Ser Professor(a): Dinâmicas Identitárias e Desenvolvimento Profissional". In Profissionalismo Docente em Transição:As Identidades dos Professores em Tempos de Mudança, edited by M. A. Flores and I. C. Viana, 155-163. Braga: Universidade do Minho, Cadernos CIED. 
Stoer, S., A. Stoleroff, and J. A. Correia. 1990. "O novo Vocacionalismo na Política Educativa em Portugal e a Reconstrução da Lógica da Acumulação." Revista Crítica de Ciências Sociais 29: 11-53.

Sugrue, C. 2004. "Rhetorics and Realities of CPD Across Europe: From Cacophony towards Coherence?" In International Handbook on the Continuing Professional Development of Teachers, edited by C. Day and J. Sachs, 67-93. Maidenhead: Open University Press.

UNESCO. 2005. A Educação Para o Século XXI: Questões e perspectivas. Porto Alegre: Artmed Editora.

\section{Legislative references}

Law No. 46/86, of 14 October - Educational System Basic Law.

Decree-Law no. 115-A/98 of 4 May - Autonomy and Management of Schools.

Decree-Law-Law No. 139-A/90 - Teaching Career First Statute.

Decree-Law No. 15/2007, of 19 January - Teaching Career Statute Reformulation.

Decree-law No. 75/2010, of 23 June - Ruling Teaching Career Statute.

Decree-Law No. 18/2011 of 2 February - Consolidation of Basic Education Curricular Organisation.

Regulatory Order No. 14/92 of 4 July - implemented the first teacher assessment policy.

Regulatory Order No. 11/2008 of 23 May - Memorandum of Understanding.

Regulatory Order No. 1-A/2009 of 5 January - Changes in Teaching Career Statute from January 2007.

Regulatory Order No. 2/2010 of 23 June 2010 - Teacher Performance Evaluation. 